Organizing Committee: Dr D. Raoux, LURE, Université Paris-Sud, Bâtiment 209 C, 91405 Orsay, France

Programme Committee: Dr A. Delapalme

\section{Powder Diffraction}

Toulouse, 16-18 July 1990

Organizing Committee: Dr J. Galy, Laboratoire de Chimie de Coordination, CNRS, 205, Route de Narbonne, 31400 Toulouse, France

Programme Committee: Professor $\mathrm{R}$ A. Young

3. Complementary Applications of Diffraction by Neutrons and by X-ray Synchrotron Radiation

Near Grenoble, 29-31 July 1990

Organizing Committee: Dr M. Marezio, Laboratoire de Cristallographie, CNRS, BP $166 \mathrm{X}, 38042$ Grenoble CEDEX, France

Programme Committee: Dr C. Vettier

4. Symmetry in Physical Space and in Superspaces. Physical Applications: Quasicrystals, Incommensurate Phases,...

Chatenay-Malabry (near Paris): 29-31 July 1990

Organizing Committee: Professor D. Weigel, Chimie-Physique du Solide, Ecole Centrale, Grande Voie des Vignes, 92295 Chatenay-Malabry CEDEX, France

Programme Committee: Professor Th. Hahn

5. International School on Crystallographic Computing

Bischenberg (near Strasbourg) 29 July5 August 1990

Organizing Committee: Dr J. C. Thierry, Laboratoire de Cristallographie Biologique, IBMC, 15, Rue Descartes, 67084 Strasbourg CEDEX, France

Programme Committee: Dr D. Moras

\section{Book Reviews}

Works intended for notice in this column should be sent direct to the Book-Review Editor (R. O. Gould, Department of Chemistry, University of Edinburgh, West Mains Road, Edinburgh EH9 $3 \mathrm{JJ}$, Scotland). As far as practicable books will be reviewed in a country different from that of publication.

J. Appl. Cryst. (1988). 21, 996

Mineralogie. By Siegfried Matthes. Pp. xvii +444 . Berlin: Springer-Verlag, 1987. Price DM 69.

This textbook (in German) could be something of a bargain for students embarking on courses in mineralogy and petrology, for it covers ground for which several texts would normally be required. This feat of précis is not achieved without expense: the treatment is neither so comprehensive and detailed nor so broad in scope as is that of the usual texts. The teacher and researcher may well bemoan this, but students will probably be grateful for its concentration on the essentials. The good value which the book offers is further enhanced by a generally high standard of book production and good clear illustrations.

Part I, on systematic mineralogy, is taken up with brief descriptions of the commoner minerals, their habit, physical properties (cleavage, streak, hardness, density, colour, lustre), chemistry, crystal structure and origin. A trained mineralogist cries out for more detail but what is given is generally sufficient for its purpose if that purpose is to enable a student to recognize typical examples of most of the minerals he is likely to encounter and know something about them. Reasonably full descriptions (with diagrams) of the crystal structure are given only for the more important minerals; otherwise only very limited information on symmetry and structure is given. Surprisingly, the feldspar structure is not illustrated or described in as much detail as one would expect for one of the commonest rock-forming minerals. It seems odd too that the reaction between calcite and quartz to form wollastonite $\left(\mathrm{CaSiO}_{3}\right)$ with release of $\mathrm{CO}_{2}$ is discussed in the section on metamorphic reactions, but no description of wollastonite appears in the systematic mineralogy section.

Part II is devoted to igneous, sedimentary and metamorphic petrology and forms an admirable introduction to the subject. The same may be said of Part III which deals with the Earth as a whole, how it is made up and functions, and more briefly with the Moon and meteorites. The essential topics are all adequately covered, though in some instances the number of examples is limited. Inevitably, within the scope of the book, the less essential topics have to receive only a brief treatment.

The combination of subject matter seems rather disjointed with three disparate sections on systematic mineralogy; igneous, sedimentary and metamorphic petrology; and basic geophysics and geochemistry. Is this another case of a university teacher turning his lecture courses into a textbook? Maybe so, but that does not lessen the quality of presentation or the author's ability to select just what a student needs to know and to judge the detail required.

J. E. CHISHOLM

Department of Mineralogy British Museum (Natural History) Cromwell Road

London SW7 5BD

England 